Almir Alihodžić ${ }^{1}$

Ilma Dedić - Grabus ${ }^{2}$

\title{
IS IT POSSIBLE TO IMPROVE BANK PERFORMANCE? EVIDENCE FROM BANKS IN BOSNIA AND HERZEGOVINA
}

\begin{abstract}
:
This research was conducted to identify variables that affect the efficiency of banks in Bosnia and Herzegovina. The required data were collected from 30 respondents (banks directors and CEOs) and a targeted set of 20 questions. For the purposes of data analysis, the statistical technique of factor analysis was used with the help of principal components. In the process of implementing this technique, the general applicability of the model and each variable was tested in order to identify key indicators that affect the efficiency of bank operations. Therefore, the main objective of this research is to identify the factors that most affect the efficiency of banks in Bosnia and Herzegovina. The results of the research showed that the value of the Kaiser-Meyer-Olkin (KMO) is greater than 0.50, which certainly confirms the application of factor analysis, that is, the significance of certain variables for the efficiency and effectiveness of banks in Bosnia and Herzegovina. Also, the factor rotation matrix indicates that the following variables have the greatest impact on the efficiency and effectiveness of banks operations: the bank provides fast service (q8), communication between the bank and clients is good (q9), the higher amount of funds held by clients in bank influences banks to meet the needs of clients when approving loans (q19), banks provide different types of loans (q14) and banks offer moderate interest rates on credit placements (q15).
\end{abstract}

Key words: Efficiency and effectiveness of bank operations, banking industry, factor analysis, bank selection decision.

JEL: $C 4, E 51, G 20, G 21$.

1 Associate professor, Faculty of Economics University of Zenica, e-mail: almir.dr2@gmail.com

2 Assistant, Faculty of Economics University of Zenica, e-mail: ilma.dedic@ef.unze.ba 


\section{INTRODUCTION}

The largest volume of services in the financial sphere in Bosnia and Herzegovina is performed by banks. The importance and significance of banking and financial services in the global services industry cannot be diminished (Mishkin, 2001). In recent years, long-term connection for clients via electronic channels has been of capital importance. The expanded range of clients as well as the wide range of different products have certainly influenced the increase of interaction with the banking sector. Today, banks are able to use a variety of channels and services, which help them reduce the cost of their operations. The factor analysis to be used in this study aims to reduce the complexity of a large number of variables in a shorter time interval by correlating between the original variables (Mendez \& Rondon, 2012). Likewise, factor analysis can be applied to the analysis of the insurance sector through the analysis of economic and financial indicators (Bezzera \& Corrar, 2006).

The structure of financial institutions in Bosnia and Herzegovina is very simple and simplified in terms of the dominant institutions such as commercial banks, general type, while other financial institutions (except insurance companies, investment funds, microcredit institutions and leasing companies) still do not have significant market share. The state, dimensions and structure of business activities of banks in Bosnia and Herzegovina can be seen from their summary balance sheets. About $60 \%$ of total bank placements relate to loans. The total number of banks in the Federation of $\mathrm{BiH}$ at the end of 2019 was 15 , while the total number of banks in the Republika Srpska in the third quarter of 2019 was 8 . All commercial banks have been modernized and computerized, where the total number of ATMs in the Federation of BiH at the end of 2019 was 1,241, while the total number of ATMs in Republika Srpska was 392. The largest number of ATMs in FBiH was from four banks (UniCredit bank - 277 ATMs, Raiffeisen bank - 282 ATMs, Intesa Sanpaolo bank - 116 ATMs and Sparkasse bank - 108 ATMs). On the other hand, the largest number of ATMs in Republika Srpska referred to three banks (Nova banka - 108, NLB bank - 73 and UniCredit bank - 59). Certainly, the modernization of the bank's operations and simplicity have an impact on attracting customers and on increasing efficiency and financial results.

In the structure of the total positive result of banks in the FB\&H at the end of 2019, the most dominant share had the following banks: Unicredit bank DD Mostar (36.90\%), Raiffeisen bank dd Sarajevo (20.77\%), then Intesa Sanpaolo bank dd Bosnia and Herzegovina (12.38\%) and Sparkasse bank dd Bosnia and Herzegovina (8.57\%). Usually, depositors and savers, when depositing money in bank accounts and opting for savings, are primarily interested in the level of the offered interest rate on time deposits, as well as a certain image that one of the banks has built in public. This 
study focuses on determining the importance of external and internal factors (mostly non-financial in nature) on the efficiency and effectiveness of bank operations in Bosnia and Herzegovina. The basic question we want to answer in this research is the following: What are the most important economic and financial variables for assessing the operations of commercial banks in Bosnia and Herzegovina?

The paper consists of five parts. The first part describes the importance of selecting and forecasting the performance of bank operations. The second part of the paper provides an overview of empirical evidence in terms of the results of the influence of internal and external factors on the efficiency of bank operations. The third part gives a brief overview of the set hypotheses and research objectives. The fourth part describes the chosen research methodology. The fifth part deals with the data necessary for the analysis and the results of the research with recommendations.

\section{Empirical Evidence}

Gerrard and Cunningham (2001) investigated the establishment of rankings of different dimensions influencing bank choice decisions for undergraduate students in Singapore, where he sought to determine how homogeneous students are in the context of their bank choice decisions. He identified seven dimensions for choosing a bank, the most important of which is a sense of security, while on the other hand the least important dimension is the influence of third parties.

Lee and Marlowe (2003) investigated through a qualitative and quantitative approach how clients choose a bank to open a current account. They came to the conclusion that most clients consider practicality and simplicity to be one of the most important criteria for decision-making. Maiyaki (2011) investigated factors that influence bank choice and selection and the decision about bank preferences. He came to the conclusion that the total assets of the bank and the availability of a larger network of branches have a great influence on the decision to choose a bank, while the attractiveness of the bank branch and the cost of the loan have less influence. Likewise, an attractive loan payment is in a less significant place, due to the religious belief of the customers.

Katirchioglu et al. (2011) analyzed the criteria for the selection of bank clients in Romania, and came to the conclusion that the Automated Teller Machine - ATM is a very important factor for the selection of a bank of clients. The availability of telephone and internet banking, the confidentiality of the bank client records, the bank's reputation and image, the presented appearance of the bank staff and the number of branches are also important for clients. Sunayna (2013) investigated the impact of service quality on customer satisfaction of the banking sector. It was concluded that improving the quality of services can have the effect of maximizing customer satisfaction. 


\section{Hypotheses and Research Goals}

The main goal of this research is to identify the factors that most affect the efficiency of banks in Bosnia and Herzegovina. Therefore, the specific goal of this research is the following:

- Identify the factors that have the greatest impact on the efficiency of banks, and on the other hand, the factors that have a smaller impact on the efficiency of operations.

$\mathrm{H}_{0}$ - There is no significant effect of internal and external factors on the efficiency of banks.

$\mathrm{H}_{1}$ - There is a significant effect of internal and external factors on the efficiency of banks.

\section{Empirical Methodology and Data}

\subsection{Empirical Methodology}

Factor analysis belongs to a group of multivariate analysis techniques that aim to examine the interdependence of multiple variables. Unlike dependence techniques, which clearly distinguish between dependent and independent variables, in factor analysis, all variables have the same status. The focus of interdependence research begs the question: How are the observed variables related? Factor analysis can be understood as a procedure used to reduce the original data to a smaller number of dimensions. In the following cases, factor analysis is applied (Soldić-Aleksić \& Chroneos-Krasavac, 2009, p. 202):

- When a group of large numbers of variables is necessary in order to extract a smaller number of variables, in order to preserve the maximum possible amount of information.

- When one wants to distinguish a basic construction-dimension or factor, which better explains the correlation between the variables being observed.

The factor analysis model in its form is reminiscent of a multiple linear regression model, where each variable can be represented as a linear combination of extracting factors, and common factors can be represented as linear combinations of the observed variables. 
If we have standardized original variables, the factor analysis model can be written as follows:

$$
X_{i}=A_{i, 1} F_{1}+A_{i, 2} F_{2}+A_{i, 3} F_{3}+\cdots+A_{i, m} F_{m}+V_{i} U_{i}
$$

Where in:

$\mathrm{x}_{i}$ - standardized variable;

$\mathrm{A}_{i j}$ - standardized multiple regression coefficient of a variable $i$ to the common factor $j$;

Fj- a common factor $j$;

$\mathrm{V} i$ - standardized variable regression coefficient $i$ to a unique factor $i$;

$\mathrm{U} i$ - a unique factor for a variety $i$;

$\mathrm{m}$ - number of common factors.

Common factors can be represented as linear combinations of the observed variables as follows:

$$
F_{i}=W_{i 1} X_{1}+W_{i 2} X_{2}+W_{i 3} X_{3}+\cdots+W_{i k} X_{k}
$$

where in:

$\mathrm{F} i$ - assessment of $i$ - factor;

W $i$ - weight or factor, coefficient score;

$\mathrm{k}$ - number of variables.

In our case, we have twenty standardized original variables and two separate factors, so the appropriate model is as follows:

$$
\begin{aligned}
& X_{1}=A_{11} F_{1}+A_{12} F_{2}+V_{1} U_{1} \\
& X_{2}=A_{21} F_{1}+A_{22} F_{2}+V_{2} U_{2} \\
& X_{3}=A_{31} F_{1}+A_{32} F_{2}+V_{3} U_{3} \\
& X_{4}=A_{41} F_{1}+A_{42} F_{2}+V_{4} U_{4} \\
& X_{5}=A_{51} F_{1}+A_{52} F_{2}+V_{5} U_{5} \\
& X_{6}=A_{61} F_{1}+A_{62} F_{2}+V_{6} U_{6} \\
& X_{7}=A_{71} F_{1}+A_{72} F_{2}+V_{7} U_{7} \\
& X_{8}=A_{81} F_{1}+A_{82} F_{2}+V_{8} U_{8} \\
& X_{9}=A_{91} F_{1}+A_{92} F_{2}+V_{9} U_{9}
\end{aligned}
$$




$$
\begin{aligned}
& X_{10}=A_{101} F_{1}+A_{102} F_{2}+V_{10} U_{10} \\
& X_{11}=A_{111} F_{1}+A_{112} F_{2}+V_{11} U_{11} \\
& X_{12}=A_{121} F_{1}+A_{122} F_{2}+V_{12} U_{12} \\
& X_{13}=A_{131} F_{1}+A_{132} F_{2}+V_{13} U_{13} \\
& X_{14}=A_{141} F_{1}+A_{142} F_{2}+V_{14} U_{14} \\
& X_{15}=A_{151} F_{1}+A_{152} F_{2}+V_{15} U_{15} \\
& X_{16}=A_{161} F_{1}+A_{162} F_{2}+V_{16} U_{16} \\
& X_{17}=A_{171} F_{1}+A_{172} F_{2}+V_{17} U_{17} \\
& X_{18}=A_{181} F_{1}+A_{182} F_{2}+V_{18} U_{18} \\
& X_{19}=A_{191} F_{1}+A_{192} F_{2}+V_{19} U_{19} \\
& X_{20}=A_{201} F_{1}+A_{202} F_{2}+V_{20} U_{20}
\end{aligned}
$$

\subsection{Data Collection and Sample}

This research is mainly based on primary data collected on the basis of a structured questionnaire consisting of twenty questions. A seven-point Likert scale was used where a value of 1 was assigned a response that was not correct at all, 2 - that was not true, 3 - more false than true, 4 - neither true nor false, 5 - more correct than incorrect, 6-true, 7 - completely true. In total, 30 directors and chairmen of the board of directors of banks in Bosnia and Herzegovina were interviewed. Data were tested for 15 banks in the Federation of Bosnia and Herzegovina and 5 banks in the Republika Srpska. In addition to the primary data, secondary data were collected from various papers and websites. Factor analysis was used to identify the factors that have the largest or the smallest impact on the performance of banks. The significance of the model was tested through the application of the Kaiser-Meyer-Olkin test. The table below the test illustrates the independent variables that are presented as questions through a questionnaire that will be tested through factor and regression analysis. 
Table 1: Selected set of variables presented through a questionnaire that have a significant impact on the efficiency and effectiveness of banks operations

\begin{tabular}{|c|l|}
\hline ID & \multicolumn{1}{|c|}{ Important factor for bank selection } \\
\hline 1. & The bank provides good service \\
\hline 2. & The bank has a convenient location \\
\hline 3. & The bank does not charge high fees. \\
\hline 4. & Bank staff are friendly. \\
\hline 5. & The bank has good working hours. \\
\hline 6. & The bank premises are tidy. \\
\hline 7. & The bank provides a large number of products to customers. \\
\hline 8. & The bank provides prompt service. \\
\hline 9. & Bank communication with clients is good. \\
\hline 10. & The bank monitors and applies the latest technological trends. \\
\hline 11. & The bank is well organized in dealing with clients. \\
\hline 12. & Bank staff are very professional. \\
\hline 13. & The bank offers high interest rates on savings. \\
\hline 14. & The bank provides different types of loans. \\
\hline 15. & The bank has a pleasant atmosphere. \\
\hline 16. & $\begin{array}{l}\text { The negative selection of debtors and the moral hazard of citizens influence the increase of } \\
\text { credit risk of banks. }\end{array}$ \\
\hline 17. & The riskiness of economic projects slows down the credit expansion of banks \\
\hline 18. & The riskiness of economic projects slows down the credit expansion of banks \\
\hline 19. & $\begin{array}{l}\text { The higher volume of clients funds in terms of bank deposits, the volume and availability } \\
\text { of services used by the clientele in the banks, influences the clients to meet and offer more } \\
\text { favorable conditions. }\end{array}$ \\
\hline 20. & $\begin{array}{l}\text { Developing new services through a franchise agreement has the effect of retaining old depo- } \\
\text { sitors and attracting new bank depositors. }\end{array}$ \\
\hline
\end{tabular}

Source: Aleksić-Soldić, J., Krasavac - Chroneous, B. (2009). Kvantitativne tehnike u istraživanju tržišta - Primena SPSS-a računarskog paketa, str. 202-203. (Adapted by the authors)

\section{Results}

The first results we obtained by applying descriptive statistics are all original variables that relate to average values and standard deviations. 
Table 2: Descriptive statistics of internal and external variables of banking sector efficiency in Bosnia and Herzegovina

\begin{tabular}{|c|c|c|c|}
\hline & Mean & Std. Deviation & Analysis N \\
\hline $\mathrm{q} 1$ & 6.10 & .885 & 30 \\
\hline $\mathrm{q} 2$ & 5.40 & 1.037 & 30 \\
\hline $\mathrm{q} 3$ & 4.90 & 1.094 & 30 \\
\hline $\mathrm{q} 4$ & 5.40 & .932 & 30 \\
\hline $\mathrm{q} 5$ & 6.00 & .871 & 30 \\
\hline $\mathrm{q} 6$ & 5.97 & .809 & 30 \\
\hline $\mathrm{q} 7$ & 4.77 & 1.501 & 30 \\
\hline $\mathrm{q} 8$ & 6.10 & .759 & 30 \\
\hline $\mathrm{q} 9$ & 6.17 & .699 & 30 \\
\hline $\mathrm{q} 10$ & 5.37 & 1.129 & 30 \\
\hline $\mathrm{q} 11$ & 5.90 & 1.029 & 30 \\
\hline $\mathrm{q} 12$ & 5.03 & 1.066 & 30 \\
\hline $\mathrm{q} 13$ & 4.90 & 1.647 & 30 \\
\hline $\mathrm{q} 14$ & 5.60 & 1.754 & 30 \\
\hline $\mathrm{q} 15$ & 4.37 & 1.829 & 30 \\
\hline $\mathrm{q} 16$ & 6.50 & .509 & 30 \\
\hline $\mathrm{q} 17$ & 5.83 & 1.053 & 30 \\
\hline $\mathrm{q} 18$ & 5.97 & .850 & 30 \\
\hline $\mathrm{q} 19$ & 5.93 & .907 & 30 \\
\hline $\mathrm{q} 20$ & 4.13 & 1.525 & 30 \\
\hline & & & \\
\hline
\end{tabular}

Source: Authors own study

The previous table shows that the variable q15 (the bank has moderate interest rates on loans) recorded the high volatility $(1.829 \%)$ with the same trend of the average value of $4.37 \%$, then the variable q14 (the bank provides different types of loans) with a standard deviation of $1,754 \%$ and a mean of $5.60 \%$. Observed on the other hand, the variables that were recorded the lowest value of the standard deviation are as follows: variable - q16 - the bank has a pleasant atmosphere (0.509), then variable q9 - the banks communication with customers is good (0.699), then variable q 8 - the bank provides fast service $(0.759)$. These observed three variables with the lowest standard deviation as a measure of volatility point to the fact that there is a pleasant atmosphere in most banks in Bosnia and Herzegovina, communication between credit officers and cashiers with customers is generally good, banks provide fast service, which is reflected in good, efficient and effective banking sector in Bosnia and Herzegovina. In banks in the Republic of Srpska as of the third quarter of 2019, the following loans had the most dominant share in the branch structure of loans to individuals: loans for general consumption (31.4\%), then loans for housing construction (11.7\%) and loans for other activities (2.9\%) (Banking Agency of Republika Srpska, 2019). Therefore, domestic banks are mainly engaged in approving classic credit operations without the presence of investment banking. The Kaiser-Meyer-Olkin measure compares the magnitudes of the observed correlation coefficients with the partial correlation coefficients. Table 3 shows the results of KMO and Bartlett's test statistics. 
Table 3: KMO and Bartlett's Test

\begin{tabular}{|c|c|c|}
\hline Kaiser-Meyer-Olkin Measur & pling Adequacy. & 0.527 \\
\hline & Approx. Chi-Square & 578.905 \\
\hline Bartlett's Test of Sphericity & df & 190 \\
\hline & Sig. & 0.000 \\
\hline
\end{tabular}

Source: Authors'own study

If the value of the KMO measure is higher than 0.50 , the application of factor analysis is recommended. In our study, the obtained value of the KMO test is 0.527 , which is greater than 0.50 , which suggests that the factor analysis can be properly implemented.

Table 4: Statistical variability of observed variables (Communalities)

\begin{tabular}{|l|l|c|}
\hline & Initial & Extraction \\
\hline q1 & 1.000 & 0.663 \\
q2 & 1.000 & 0.839 \\
q3 & 1.000 & 0.852 \\
q4 & 1.000 & 0.864 \\
q5 & 1.000 & 0.702 \\
q6 & 1.000 & 0.861 \\
q7 & 1.000 & 0.949 \\
q8 & 1.000 & 0.865 \\
q9 & 1.000 & 0.891 \\
q10 & 1.000 & 0.837 \\
q11 & 1.000 & 0.806 \\
q12 & 1.000 & 0.869 \\
q13 & 1.000 & 0.948 \\
q14 & 1.000 & 0.947 \\
q15 & 1.000 & 0.923 \\
q16 & 1.000 & 0.850 \\
q17 & 1.000 & 0.825 \\
q18 & 1.000 & 0.814 \\
q19 & 1.000 & 0.906 \\
q20 & 1.000 & 0.872 \\
\hline
\end{tabular}

Source: Authors own study

In this research, we chose the procedure of the principal components as a method of factor extraction. Also, for the criterion of choosing the number of factors, we took the characteristic values associated with factors that are greater than 1 . 
Table 5: Total Variance Explained

\begin{tabular}{|c|c|c|c|c|c|c|c|c|c|}
\hline \multirow{2}{*}{ Component } & \multicolumn{3}{|c|}{ Initial Eigenvalues } & \multicolumn{3}{|c|}{$\begin{array}{l}\text { Extraction Sums of Squared } \\
\text { Loadings }\end{array}$} & \multicolumn{3}{|c|}{$\begin{array}{l}\text { Rotation Sums of Squared } \\
\text { Loadings }\end{array}$} \\
\hline & Total & $\begin{array}{c}\text { \% of } \\
\text { Variance }\end{array}$ & $\begin{array}{c}\text { Cumulative } \\
\%\end{array}$ & Total & $\begin{array}{c}\% \text { of } \\
\text { Variance }\end{array}$ & $\begin{array}{c}\text { Cumulative } \\
\%\end{array}$ & Total & $\begin{array}{c}\text { \% of } \\
\text { Variance }\end{array}$ & $\begin{array}{c}\text { Cumulative } \\
\%\end{array}$ \\
\hline 1 & 6.219 & 31.094 & 31.094 & & & & & & \\
\hline 2 & 3.367 & 16.833 & 47.927 & & & & & & \\
\hline 3 & 2.863 & 14.317 & 62.244 & & & & & & \\
\hline 4 & 2.227 & 11.135 & 73.379 & & & & & & \\
\hline 5 & 1.386 & 6.932 & 80.311 & & & & & & \\
\hline 6 & 1.023 & 5.114 & 85.426 & & & & & & \\
\hline 7 & 0.845 & 4.227 & 89.653 & & & & & & \\
\hline 8 & 0.510 & 2.548 & 92.200 & 6.219 & 31.094 & 31.094 & 4.090 & 20.449 & 20.449 \\
\hline 9 & 0.408 & 2.042 & 94.242 & 3.367 & 16.833 & 47.927 & 3.303 & 16.516 & 36.965 \\
\hline 10 & 0.293 & 1.465 & 95.707 & 2.863 & 14.317 & 62.244 & 2.867 & 14.336 & 51.301 \\
\hline 11 & 0.232 & 1.160 & 96.867 & 2.227 & 11.135 & 73.379 & 2.630 & 13.150 & 64.450 \\
\hline 12 & 0.189 & 0.943 & 97.810 & 1.386 & 6.932 & 80.311 & 2.605 & 13.026 & 77.476 \\
\hline 13 & 0.132 & 0.662 & 98.472 & 1.023 & 5.114 & 85.426 & 1.590 & 7.950 & 85.426 \\
\hline 14 & 0.111 & 0.556 & 99.028 & & & & & & \\
\hline 15 & 0.067 & 0.335 & 99.363 & & & & & & \\
\hline 16 & 0.049 & 0.247 & 99.610 & & & & & & \\
\hline 17 & 0.032 & 0.161 & 99.770 & & & & & & \\
\hline 18 & 0.020 & 0.101 & 99.871 & & & & & & \\
\hline 19 & 0.017 & 0.084 & 99.955 & & & & & & \\
\hline 20 & 0.009 & 0.045 & 100.000 & & & & & & \\
\hline
\end{tabular}

Source: Authors own study

As can be seen from the previous table, the first six factors have characteristic values greater than 1, where the percentage of explaining variance for these six factors is $85 \%$. Since we have chosen the factors, the next step in the factor analysis process is the rotation and interpretation of the factors. Since we have chosen to display only those factor weights that are greater than 0.3 , it can be seen that some fields in table 6 are empty. We come to the conclusion that it is very difficult to single out only certain variables that best explain the influence of certain factors. In this regard, the factor rotation process is approached. 
Table 6: Component Matrix

\begin{tabular}{|c|c|c|c|c|c|c|}
\hline & \multicolumn{6}{|c|}{ Component } \\
\hline & 1 & 2 & 3 & 4 & 5 & 6 \\
\hline q20 & 0.895 & & & & & \\
\hline q14 & 0.857 & 0.328 & & & & \\
\hline q13 & 0.823 & 0.303 & 0.580 & & & \\
\hline q15 & 0.773 & -0.475 & & & & \\
\hline q7 & 0.717 & & & & & \\
\hline q11 & 0.666 & 0.583 & & & & \\
\hline q9 & 0.653 & 0.415 & & & & \\
\hline q8 & 0.606 & 0.442 & & 0.315 & & 0.422 \\
\hline $\mathrm{q} 3$ & 0.576 & -0.392 & & 0.419 & & 0.430 \\
\hline $\mathrm{q} 2$ & 0.477 & -0.708 & & & & -0.361 \\
\hline q19 & 0.368 & 0.658 & & 0.491 & & \\
\hline q17 & -0.455 & 0.598 & 0.815 & 0.345 & & \\
\hline q5 & 0.471 & -0.496 & 0.593 & & 0.359 & 0.383 \\
\hline $\mathrm{q} 4$ & & & 0.391 & & & \\
\hline q1 & & & -0.607 & -0.307 & & \\
\hline q10 & -0.381 & & 0.442 & 0.703 & & \\
\hline q18 & & & & 0.630 & 0.855 & \\
\hline q12 & 0.335 & -0.465 & -0.390 & 0.508 & 0.545 & \\
\hline q16 & & & & & & \\
\hline q6 & 0.492 & -0.360 & & & & \\
\hline
\end{tabular}

Source: Authors own study 
Table 7: Rotated Component Matrix

\begin{tabular}{|c|c|c|c|c|c|c|}
\hline & \multicolumn{6}{|c|}{ Component } \\
\hline & 1 & 2 & 3 & 4 & 5 & 6 \\
\hline q8 & & & & & & \\
\hline $\mathrm{q} 9$ & & & & & & \\
\hline $\mathrm{q} 11$ & & & & & & \\
\hline $\mathrm{q} 19$ & & & & & & \\
\hline $\mathrm{q} 14$ & & & & & & \\
\hline q11 & & & & & & \\
\hline q15 & & & & & & \\
\hline q5 & & & & & & \\
\hline q17 & 0.921 & & & & & \\
\hline $\mathrm{q} 2$ & 0.899 & & & & & \\
\hline $\mathrm{q} 10$ & 0.831 & 0.820 & & & & \\
\hline q13 & 0.667 & 0.803 & & 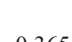 & 27 & \\
\hline q4 & 0.642 & -0.785 & & م & & \\
\hline q20 & & 0.741 & 0 & 0863 & & \\
\hline q3 & & & 0.756 & & & \\
\hline q12 & & & -0.738 & & & 0.892 \\
\hline q18 & & & & & & 0.735 \\
\hline $\mathrm{q} 1$ & & & & & & \\
\hline q7 & & & & & & \\
\hline q16 & & & & & & \\
\hline q6 & & & & & & \\
\hline
\end{tabular}

Source: Authors own study

From the previous table, it is completely clear that after the rotation of the factors, factor matrix was obtained, where it can be seen that high values of factor weights belonging to a small number of variables can be assigned and separated for each factor. By way of illustration, the previous table shows that a larger number of variables have high positive weights with the fourth factor, while on the other hand, a smaller number of variables have high negative weights with the fourth factor. Positive variables with the fourth factor are the following: $\mathrm{q} 8$ - the bank provides prompt service, q9 - bank communication with clients is good, q11 - the bank monitors and applies the latest technological trends, q19 - the higher volume of clients funds in terms of bank deposits, the volume and availability of services used by the clientele in the banks, influences the clients to meet and offer more favorable conditions, q14 - the bank provides different types of loans, q15 - the bank has moderate interest rates on loans, $\mathrm{q} 5$ - the bank has a good working time, $\mathrm{q} 2$-the bank has a convenient location, q13 - the bank offers high interest rates on savings, q20- developing new services through a franchise agreement has the effect of retaining old depositors and attracting new bank depositors, q3 - the bank does not charge high fees, q12 - Bank 
staff are very professional, q1 - the bank provides good service, q16 - the bank has a pleasant atmosphere and $\mathrm{q} 6$ - the banks premises are tidy. The squares of these correlation coefficients represent the proportions of the variance of certain variables attributed to the action of a given factor. In our research for the first factor we have the following:

$$
\begin{aligned}
& 0.9212=0.8482 \\
& 0.8992=0.8082 \\
& 0.8312=0.6905 \\
& 0.6672=0.4448 \\
& 0.6422=0.4122
\end{aligned}
$$

Based on the previous calculation, we can conclude that the first factor explains $84.82 \%$ of the variance of the variable $\mathrm{q} 8$ - the bank provides prompt service, $69.05 \%$ of the variance of the variable $\mathrm{q} 9$ - bank communication with clients is good, $69.05 \%$ of the variance of the variable q11 - the bank is well organized in dealing with clients and $41.22 \%$ variance of variable q14 - the bank provides different types of loans. Based on the previous rotating matrix, using factor analysis, we reduced the previous 20 variables to a total of six factors and five variables.

Table 8: Component Score Coefficient Matrix

\begin{tabular}{|c|c|c|c|c|c|c|}
\hline & \multicolumn{6}{|c|}{ Component } \\
\cline { 2 - 7 } q1 & 1 & 2 & 3 & 4 & 5 & 6 \\
q2 & 0.046 & -0.105 & -0.040 & -0.061 & 0.307 & 0.155 \\
q3 & -0.010 & 0.223 & -0.081 & 0.076 & -0.118 & 0.050 \\
q4 & -0.085 & -0.078 & 0.067 & 0.414 & -0.050 & -0.080 \\
q5 & 0.123 & 0.041 & -0.342 & 0.014 & 0.169 & 0.090 \\
q6 & 0.080 & 0.341 & -0.109 & -0.200 & -0.049 & 0.055 \\
q7 & 0.004 & 0.029 & 0.013 & 0.072 & -0.028 & 0.439 \\
q8 & 0.007 & -0.073 & 0.067 & 0.171 & 0.263 & 0.063 \\
q9 & 0.349 & 0.117 & -0.236 & -0.178 & -0.054 & 0.021 \\
q10 & 0.328 & 0.151 & -0.211 & -0.181 & -0.020 & -0.112 \\
q11 & 0.075 & -0.041 & -0.317 & 0.136 & -0.086 & 0.042 \\
q12 & 0.221 & -0.036 & 0.011 & -0.068 & 0.007 & 0.041 \\
q13 & -0.073 & -0.089 & -0.057 & 0.406 & 0.008 & -0.002 \\
q14 & 0.029 & -0.073 & 0.261 & 0.055 & 0.038 & 0.093 \\
q15 & 0.060 & -0.081 & 0.176 & 0.116 & 0.121 & -0.065 \\
q16 & 0.008 & 0.250 & 0.047 & -0.019 & -0.028 & -0.051 \\
q17 & -0.011 & -0.039 & -0.048 & -0.090 & 0.106 & 0.610 \\
q18 & 0.029 & -0.292 & 0.045 & 0.065 & -0.101 & 0.160 \\
q19 & 0.100 & -0.019 & -0.075 & 0.013 & -0.342 & 0.047 \\
q20 & 0.140 & -0.216 & 0.087 & 0.147 & -0.180 & -0.003 \\
& 0.034 & 0.022 & 0.164 & 0.104 & -0.023 & 0.043 \\
\hline
\end{tabular}


From the previous table, it is evident that for the first factor, the following variables recorded high values of the coefficients: q8, q9, q11 and q19. For the second factor we have high values of the coefficients for the following variables: q5, q15, q2, q9 and q8. For the third factor, high values were recorded for the following variables: q13, q14 and q20. In the fourth factor, high values were achieved for the following variables: q3, q12, q7 and q14. For the fifth factor, high values were recorded for the following variables: q1, q7 and q4. For the sixth factor, high values were achieved for the following variables: q16, q6, q17 and q1. In further research, we will test the correlation of the following variables (q8, q9, q11,q14, and q19) on the efficiency of banks in Bosnia and Herzegovina, and on profitability indicators (ROA, and ROE) through regression and correlation analysis. The table below illustrates the outputs of the regression model. Also, table 9 shows the correlation coefficients of individual variables and dependent variables in the model (ROA and ROE).

Table 9: Correlation between dependent and independent variables of banks in Bosnia and Herzegovina for the period: 2013: Q1 - 2019:Q4

\begin{tabular}{|c|c|c|c|c|c|c|c|c|}
\hline & & ROA & ROE & q8 & q9 & q11 & q14 & q19 \\
\hline \multirow{3}{*}{ ROA } & $\begin{array}{c}\text { Pearson } \\
\text { Correlation }\end{array}$ & 1.000 & 1.000 & 0.787 & 0.790 & 0.815 & 0.812 & 0.745 \\
\hline & Sig. (2-tailed) & & 0.000 & 0.004 & 0.002 & 0.000 & 0.000 & 0.003 \\
\hline & $\mathbf{N}$ & 28 & 28 & 28 & 28 & 28 & 28 & 28 \\
\hline \multirow{3}{*}{ ROE } & $\begin{array}{c}\text { Pearson } \\
\text { Correlation }\end{array}$ & 1.000 & 1.000 & 0.785 & 0.790 & 0.817 & 0.810 & 0.745 \\
\hline & Sig. (2-tailed) & 0.000 & & 0.000 & 0.000 & 0.000 & 0.000 & 0.000 \\
\hline & $\mathbf{N}$ & 28 & 28 & 28 & 28 & 28 & 28 & 28 \\
\hline \multirow{3}{*}{ q8 } & $\begin{array}{c}\text { Pearson } \\
\text { Correlation }\end{array}$ & 0.785 & 0.787 & 1.000 & 0.871 & 0.615 & 0.537 & 0.539 \\
\hline & Sig. (2-tailed) & 0.004 & 0.000 & & 0.000 & 0.000 & 0.003 & 0.003 \\
\hline & $\mathbf{N}$ & 28 & 28 & 28 & 28 & 28 & 28 & 28 \\
\hline \multirow{3}{*}{ q9 } & $\begin{array}{c}\text { Pearson } \\
\text { Correlation }\end{array}$ & 0.790 & 0.790 & 0.871 & 1.000 & 0.632 & 0.640 & 0.426 \\
\hline & Sig. (2-tailed) & 0.002 & 0.000 & 0.000 & & 0.000 & 0.000 & 0.024 \\
\hline & $\mathbf{N}$ & 28 & 28 & 28 & 28 & 28 & 28 & 28 \\
\hline \multirow{3}{*}{ q11 } & $\begin{array}{c}\text { Pearson } \\
\text { Correlation }\end{array}$ & 0.817 & 0.815 & 0.615 & 0.632 & 1.000 & 0.695 & 0.564 \\
\hline & Sig. (2-tailed) & 0.000 & 0.000 & 0.000 & 0.000 & & 0.000 & 0.002 \\
\hline & $\mathbf{N}$ & 28 & 28 & 28 & 28 & 28 & 28 & 28 \\
\hline \multirow{3}{*}{ q14 } & $\begin{array}{c}\text { Pearson } \\
\text { Correlation }\end{array}$ & 0.810 & 0.812 & 0.537 & 0.640 & 0.695 & 1.000 & 0.419 \\
\hline & Sig. (2-tailed) & 0.000 & 0.000 & 0.003 & 0.000 & 0.000 & & 0.026 \\
\hline & $\mathbf{N}$ & 28 & 28 & 28 & 28 & 28 & 28 & 28 \\
\hline \multirow{3}{*}{ q19 } & $\begin{array}{c}\text { Pearson } \\
\text { Correlation }\end{array}$ & 0.745 & 0.745 & 0.539 & 0.426 & 0.564 & 0.419 & 1.000 \\
\hline & Sig. (2-tailed) & 0.003 & 0.000 & 0.003 & 0.024 & 0.002 & 0.026 & \\
\hline & $\mathbf{N}$ & 28 & 28 & 28 & 28 & 28 & 28 & 28 \\
\hline
\end{tabular}

Source: Authors own study 
From the previous table it is evident that all five independent variables have a very positive correlation of the dependent variables (ROA and ROE) of banks in Bosnia and Herzegovina. The total number of observations is 28 . The strongest positive relationship with the first profitability indicator (ROA) was recorded by the following variables: q 11 - the bank has a good organization of dealings with clients (0.815) and q14 - the bank provides different types of loans (0.812). Also, the variables q9 had a high value - the bank's communication with clients is good, as well as the variable q8 - the bank provides fast service. All independent variables have a high significance of less than $5 \%$.

The results obtained by regression analysis indicate that the coefficient of correlation is, which indicates that there is a strong correlation between the dependent variable, i.e., return on assets (ROA) and independent variables: higher volume of client funds in the context of bank deposits, volume and availability of services customers are met and offered more favorable terms (q19), the bank provides different types of loans (q14), the bank provides fast service (q8), the bank has a good organization of work with clients (q11) and the bank's communication with clients is good (q9).

Table 10: Regression analysis between the following parameters: ROA, q19, q14, q8, q11 and q9 for the period: 2013: Q1 - 2019: Q4

\begin{tabular}{|c|c|c|c|c|c|}
\hline Model & R & R Square & $\begin{array}{c}\text { Adjusted R } \\
\text { Square }\end{array}$ & $\begin{array}{c}\text { Std. Error of } \\
\text { the Estimate }\end{array}$ & $\begin{array}{c}\text { Durbin-Wat- } \\
\text { son }\end{array}$ \\
\hline 1 & 0.971 & 0.942 & 0.929 & 0.2736 & 1.852 \\
\hline
\end{tabular}

Source: Authors own study

Also, the coefficient of determination of the regression model is 0.942 , which indicates that almost $94 \%$ of the variability of the dependent variable ROA can be explained by the above five factors. Based on the realized level of significance in the ANOVA table, we come to the conclusion that the coefficient of determination is statistically significantly different from zero (the last column in the table 11).

Table 11: ANOVA test between dependent and independent variables for the period: 2013: Q1 - 2019: Q4

\begin{tabular}{|c|c|c|c|c|c|}
\hline Model & $\begin{array}{c}\text { Sum of } \\
\text { Squares }\end{array}$ & df & Mean Square & F & Sig. \\
\hline 1 Regression & 26.782 & 6 & 5.356 & 71.561 & 0.000 \\
\hline Residual & 1.647 & 22 & 0.075 & & \\
\hline Total & 28.429 & 28 & & & \\
\hline
\end{tabular}

Source: Authors own study

Regarding the testing of the null and alternative hypothesis through the empirical and theoretical F-test, we came to the following conclusion: The empirical value of the $\mathrm{F}$ test for 6 degrees of freedom in the numeration and 22 in the denomination 
was 71.56. The obtained empirical value of the F test is 71.56 (by $5 \%$ significance), which is more than the theoretical value (2.55), which rejects the zero hypotheses and confirms the alternative hypothesis, and also confirms the individual influence of independent variables on the dependent variable (ROA).

The table 12 shows the regression coefficients for five factors and their influence on the dependent variable - ROA.

Table 12: Regression analysis of coefficients between the following variables: ROA, q8, q9, q11, q14, q19 for the period: 2013: Q1 - 2019: Q4

\begin{tabular}{|c|c|c|c|c|c|}
\hline \multirow{2}{*}{ Model } & \multicolumn{2}{|c|}{ Unstandardized Coefficients } & $\begin{array}{c}\text { Standardized } \\
\text { Coefficients }\end{array}$ & \multirow{2}{*}{ t } & \multirow{2}{*}{ Sig. } \\
\cline { 2 - 4 } & B & Std. Error & Beta & & \\
\hline 1 (Constant) & -1.534 & 0.535 & - & -2.868 & 0.009 \\
\hline q8 & 0.213 & 0.153 & 0.159 & 1.387 & 0.179 \\
\hline q9 & 0.248 & 0.172 & 0.171 & 1.448 & 0.162 \\
\hline q11 & 0.165 & 0.081 & 0.168 & 2.045 & 0.053 \\
\hline q14 & 0.204 & 0.044 & 0.357 & 4.598 & 0.000 \\
\hline q19 & 0.384 & 0.075 & 0.343 & 5.142 & 0.000 \\
\hline
\end{tabular}

Source: Authors own study

In the last column it can be seen that the significance of zero was recorded for the variable q14 (the bank provides different types of loans) as well as for the variable q19 (higher volume of client funds in terms of bank deposits, volume and availability of services meets and offers more favorable conditions) which obviously implies the conclusion that the observed two variables can influence as significant predictors of the variable return on asset (ROA) of banks in Bosnia and Herzegovina. This is especially true for variable q19, where indeed banks are more flexible in the context of granting loans and other benefits to customers who have more open accounts in one of the banks and a higher volume of transactions. The results obtained by regression analysis indicate that the coefficient of correlation is, which indicates that there is a strong correlation between the dependent variable, i.e., return on equity (ROE) and independent variables: higher volume of client funds in the context of bank deposits, volume and availability of services customers are met and offered more favorable terms (q19), the bank provides different types of loans (q14), the bank provides fast service (q8), the bank has a good organization of work with clients (q11) and the banks communication with clients is good (q9). 
Table 13: Regression analysis between the following parameters: ROE, q19, q14, q8, q11 and q9 for the period: 2013: Q1 - 2019: Q4

\begin{tabular}{|c|c|c|c|c|c|}
\hline Model & $\mathbf{R}$ & R Square & $\begin{array}{c}\text { Adjusted R } \\
\text { Square }\end{array}$ & $\begin{array}{c}\text { Std. Error of } \\
\text { the Estimate }\end{array}$ & $\begin{array}{c}\text { Durbin-Wat- } \\
\text { son }\end{array}$ \\
\hline 1 & 0.953 & 0.908 & 0.887 & 0.2892 & 1.855 \\
\hline
\end{tabular}

Source: Authors own study

Also, the coefficient of determination of the regression model is 0.908 , which indicates that almost $91 \%$ of the variability of the another dependent variable return on equity ROE) can be explained by the above five factors. Based on the realized level of significance in the ANOVA table, we come to the conclusion that the coefficient of determination is statistically significantly different from zero (the last column in the table 14).

Table 14: ANOVA test between dependent and independent variables for the period: 2013: Q1 - 2019: Q4

\begin{tabular}{|c|c|c|c|c|c|}
\hline Model & $\begin{array}{c}\text { Sum of Squ- } \\
\text { ares }\end{array}$ & df & Mean Square & F & Sig. \\
\hline 1 Regression & 18.160 & 6 & 3.632 & 43.432 & 0.000 \\
\hline Residual & 1.840 & 22 & 0.084 & & \\
\hline Total & 20.000 & 28 & & & \\
\hline
\end{tabular}

Source: Authors own study

The table 15 shows the regression coefficients for five factors and their influence on the dependent variable - return on equity (ROE). From the previous table, it can be concluded that the obtained empirical test is (43.43) (for 6 degrees of freedom in the numerator and 22 degrees of freedom in the denominator), which is higher than the theoretical test by $5 \%$ significance, which is 2.55 . Therefore, the empirical test is larger than the theoretical test, which implies the conclusion that certain independent variables have an impact on the dependent variables.

Table 15: Regression analysis of coefficients between the following variables: ROE, q8, q9, q11, q14, q19 for the period: 2013: Q1 - 2019: Q4

\begin{tabular}{|c|c|c|c|c|c|}
\hline \multirow{2}{*}{ Model } & \multicolumn{2}{|c|}{ Unstandardized Coefficients } & $\begin{array}{c}\text { Standardized } \\
\text { Coefficients }\end{array}$ & \multirow{2}{*}{ t } & \multirow{2}{*}{ Sig. } \\
\cline { 2 - 4 } & B & Std. Error & Beta & & \\
\hline 1 (Constant) & -0.714 & 0.565 & - & -1.264 & 0.220 \\
\hline q8 & -0.072 & 0.162 & -0.064 & -0.444 & 0.662 \\
\hline q9 & 0.656 & 0.181 & 0.538 & 3.618 & 0.002 \\
\hline q11 & 0.250 & 0.085 & 0.303 & 2.928 & 0.008 \\
\hline q14 & 0.059 & 0.047 & 0.123 & 1.253 & 0.223 \\
\hline q19 & 0.226 & 0.079 & 0.241 & 2.866 & 0.009 \\
\hline
\end{tabular}

Source: Authors own study 
It is evident from the table... that the strongest influence is on the second dependent variable, i.e., return on equity (ROE) was recorded with variable q9 (the banks communication with clients is good) with a significance of 0.002 . The choice of indicators for customer analysis can vary from country to country, or from bank to bank. Indicators are usually adjusted to the specifics of market conditions and participants. In developed markets, i.e., in countries where there is a competitive system, indicators for the needs of client analysis are of capital importance. However, in less competitive systems such as Bosnia and Herzegovina, detailed analyses are not needed, but a rough assessment of financial and non-financial indicators is. In such markets, direct knowledge of clients is much more important because the indicators are often not sufficient and are not always correct (Plakalović \& Alihodžić, 2015).

\section{CONCLUSION}

In this study, we used factor analysis to identify which variables best explain the maximum deviation from the smallest number of variables. The results of the research showed that the non-financial and financial variables that have the greatest impact on the effectiveness and efficiency of banks in Bosnia and Herzegovina are as follows: the banks communication with customers is good, the bank has a good organization of work with clients, the bank provides different types of loans, greater volume of clients funds in terms of bank deposits, volume and availability of services used by clients in banks influences that clients' needs are met and they are offered more favorable conditions. Therefore, out of a total of twenty independent variables, a total of six variables best explain the total data variations by about $85.43 \%$. For this purpose, this study took place for the banking sector of Bosnia and Herzegovina in the period from 2013: Q1 - 2019: Q4 starting from the research part of the paper through underlying factor analysis, then additionally comparing empirical and theoretical F-test in terms of testing null and alternative hypothesis. The results showed that zero hypothesis was rejected and that an alternative hypothesis was accepted in terms of some independent variables that have a significant influence on the ROA and ROE. Factors such as: the bank has a good organization of business with clients, communication of the bank with the banks clients, the higher volume of clients funds in terms of bank deposits, the volume and availability of services used by clients in banks influences that clients are met and offer more favorable conditions, have a significant impact on analyzing and improving the performance of institutions for better future positioning in the banking market, and attracting additional customers. Therefore, the obtained results of this research with the help of factor analysis as a statistical tool can be useful for managers of banks in the Republic of Srpska and the Federation of Bosnia and Herzegovina to assess the business of banking institutions through the economic and financial prism. We hope that this research will increase the awareness and knowledge of managers in banks in Bosnia and Herzegovina about the importance of new (especially) non-financial indicators on the indirect impact on business profitability. 


\section{REFERENCES:}

1. Aleksić-Soldić, J., Krasavac, Croneous, B. (2009). Kvantitativne tehnike u istraživanju tržišta - primena SPSS računskog paketa, Centar za izdavačku delatnost Ekonomskog fakulteta u Beogradu.

2. Banking Agency of Republika Srpska (2019). Report on Condition of the Banking System of Republika Srpska. Retrieved from: https://abrs.ba/public/data/ documents/1352/20190930_Izvjestaj_o_stanju_bankarskog_sistema_RS.pdf

3. Banking Agency of the Federation of Bosnia and Herzegovina (2019). Information on the Banking System Entities of the Federation of Bosnia and Herzegovina. Retrieved from: https://www.fba.ba/upload/docs/informacija_o_bankarskom_sistemu_30092019_eng_fra.pdf.

4. Bezerra,F.A.,Corrar,L.J.(2006). Utilização da factor analysisnaidentificação dos principaisindicadores paraavaliaçãodo desempenhofinanceiro:umaaplicaçãonas empresas de seguros. Revista Contabilidade \& Finanças, 17(42), pp. 50-62.

5. Gerrard, P. Cunningham J.B. (2001). Bank service quality: a comparison between a publicly quoted bank and a government bank in Singapore. J. Finan. Serv. Mark., 6(1): pp. 50-66.

6. Katircioglu, S.T., Tumer, M., Kilinc, C. (2011). Bank Selection Criteria in the Banking Industry: An Empirical Investigation from Customers in Romanian Cities. African Journal of Business Management, Vol. 5(14), pp. 5551-5558.

7. Lee,J., Marlowe, J. (2003). How consumers choose a financial institution: Decision-making criteria and heuristics. Int. J. Bank Mark., 21(2): pp.53-71.

8. Maiyaki, A. A. (2011). Factors Determining Bank's Selection and Preference in Nigerian Retail Banking. International Journal of Business and Management, $6(1)$.

9. Méndez, M.C., Rondón, M. A. S. (2012). Introducción al análisis factorial exploratorioIntroduction to Exploratory Factor Analysis, Revista Colombiana de Psiquiatria, Vol. 41, Issue 1, pp. 197-207.

10. Plakalović, N., Alihodžić, A. (2015). Novac, banke i finansijska tržišta, Ekonomski fakultet u Banjaluci: Banjaluka.

11. Sunayna (2013). Service Quality versus Customer Satisfaction in the Banking Sector. International Journal of Business and Social Science, Vol. 4 No. 10 , pp.49-56. 
Almir Alihodžić

Ilma Dedić - Grabus

\section{DA LI JE MOGUĆE POBOLJŠATI PERFORMANSE POSLOVANJA BANAKA: EVIDENCIJA BANAKA U BOSNI I HERCEGOVINI?}

\section{SAŽETAK}

Ovo istraživanje je sprovedeno u cilju identifikovanja varijabli koje utiču na efikasnost poslovanja banaka u Bosni i Hercegovini. Potrebni podaci prikupljeni su od 30 ispitanika (direktora i predsjednika uprave banaka) i ciljnog seta od 20 pitanja. Za potrebe analize podataka korištena je statistička tehnika faktorske analize uz pomoć analize glavnih komponenti. U procesu implementacije ove tehnike testirana je opšta primjenljivost modela te svake varijable u cilju identifikovanja ključnih pokazatelja koji utiču na efikasnost poslovanja banaka. Dakle, glavni cilj ovog istraživanja jeste da se identifikuju faktori koji najviše utiču na efikasnost poslovanja banaka u Bosni i Hercegovini. Rezultati istraživanja su pokazali da je vrijednost Kaiser-Meyer-Olkin testa veća od 0,50, što svakako potvrđuje primjenu faktorske analize, odnosno značajnosti određenih varijabli na efikasnost i efektivnost poslovanja banaka u Bosni i Hercegovini. Također, matrica rotacije faktora ukazuje da sljedeće promjenjive imaju najveći uticaj na efikasnost i efektivnost poslovanja banaka: banka pruža brzu uslugu (q8), komunikacija banke sa klijentima je dobra (q9), veći obim sredstava koji klijenti drže u bankama utiče da banke klijentima izlaze u susret prilikom odobravanja kredita (q19), banke daju različite tipove kredita (q14) i banke nude umjerene kamatne stope na kreditne plasmane (q15).

Ključne riječi: Efektivnost $i$ efikasnost bankarskog poslovanja, bankarska industrija, faktorska analiza, odluka o odabiru banke.

JEL: C4, E51, G20, G21. 